\title{
Synthesis of Poly(methyl methacrylate)-b-poly(N-isopropylacrylamide) Block Copolymer by Redox Polymerization and Atom Transfer Radical Polymerization
}

\author{
Melahat Göktaş ${ }^{1, *}$ and Guodong Deng ${ }^{2}$ \\ ${ }^{1}$ Yüzüncü Yıl University, Department of Science Education, Van, 65100, Turkey \\ 2University of Akron, Department of Polymer Engineering, 250 S Forge St, Akron, OH 44325 USA
}

Received September 29, 2017; Accepted January 2, 2018

\begin{abstract}
Poly(methyl methacrylate)-b-poly(N-isopropylacrylamide) [PMMA-b-PNIPAM] block copolymers were obtained by a combination of redox polymerization and atom transfer radical polymerization (ATRP) methods in two steps. For this purpose, PMMA macroinitator (ATRP-macroinitiator) was synthesized by redox polymerization of methyl methacrylate and 3-bromo-1-propanol using $\mathrm{Ce}\left(\mathrm{NH}_{4}\right)_{2}\left(\mathrm{NO}_{3}\right)_{6}$ as a catalyst. The synthesis of PMMA-b-PNIPAM block copolymers was carried out by means of ATRP of ATRP-macroinitiator and NIPAM at $60{ }^{\circ} \mathrm{C}$. The block copolymers were obtained in high yield and high molecular weight. The characterization of products was accomplished by using multi instruments and methods such as nuclear magnetic resonance spectroscopy, Fourier transform infrared spectroscopy, gel permeation chromatography, and thermogravimetric analysis.
\end{abstract}

Keywords: atom transfer radical polymerization; redox polymerization; macroinitiator; block copolymer; methyl methacrylate

\section{ABSTRAK}

Kopolimer blok poli(metil metakrilat)-b-poli(N-isopropilakrilamina) [PMMA-b-PNIPAM] telah didapatkan dalam dua tahap melalui kombinasi metode polimerisasi redoks dan polimerisasi radikal transfer atom (atom transfer radical polymerization, ATRP). Dalam hal ini, makroinisiator PMMA (makroinisiator ATRP) disintesis melalui polimerisasi redoks antara metil metakrilat dan 3-bromi-1-propanol menggunakan $\mathrm{Ce}\left(\mathrm{NH}_{4}\right)_{2}\left(\mathrm{NO}_{3}\right)_{6}$ sebagai katalis. Sintesis kopolimer blok PMMA-b-PNIPAM dilakukan dengan menggunakan makroinisiator ATRP dan NIPAM pada $60{ }^{\circ} \mathrm{C}$. Kopolimer blok diperoleh dengan rendemen dan masa molekul yang tinggi. Karakterisasi produk menggunakan berbagai metode meliputi spektroskopi resonansi magnetik inti, spektroskopi infra merah, kromatografi permeasi gel, dan analisis termogravimetri.

Kata Kunci: polimerisasi radikal transfer atom; polimerisasi redoks; makroinisiator; kopolimer blok; metil metakrilat

\section{INTRODUCTION}

Recently, many research groups have been working on living-controlled radical polymerization techniques, such as Nitroxide-Mediated Polymerization (NMP) [1], Atom Transfer Radical Polymerization (ATRP) [2] and Reversible Addition/Fragmentation Chain Transfer (RAFT) Polymerization [3]. Controlled radical polymerization techniques are based on radical closing mechanisms and agents [4-6,]. After intensive studies on ionic-living polymerization techniques, it has recently become important to develop free-radical polymerization that can demonstrate the characteristics of living polymerization techniques [7]. Controlled/"living" radical polymerization (CRP) has been enabled the synthesis of polymers which have narrow molecular weight distribution and a well-defined structure because all chains are growing at equal rate, or in other words, the molecular weight increases linearly with conversion [89].

Since Wang and Matyjaszewski suggested the idea of ATRP [10] in 1995, the polymers with low polydispersity index, including poly (methyl) acrylates, styrene, acrylonitrile etc. have been synthesized by using the Cu-based catalytic system ATRP that has many advantages as compared with other CRPs [1112]. The diversity of the ATRP is proved by its compatibility with a very wide range of monomers and reaction conditions [13-14]. Many redox pairs containing organic and inorganic components as polymerization initiator have been successively used. In these redox initiation systems, free radicals are produced by the oxidation of the substrate, which in turn initiate the polymerization. A kind of redox initiation system, salt of $\mathrm{Ce}(\mathrm{IV})$ oxidized a primary alcohol leading to radical formation [15-17].

* Corresponding author.

Email address : melahat 36@hotmail.com

DOI: 10.22146/ijc.28645 
The well-defined synthesis of block copolymers is a significant topic in macromolecular chemistry [18]. Block copolymers that provide particular combinations of physical properties are the nearly appropriate materials for different purposes [19]. Macroinitiators have been broadly used for designing diverse block copolymers via a radical set off process [20-21]. Synthesis of block copolymers have recently been successful in the by the combination of different techniques. Block copolymers that have excellent physical properties are some of the most important polymeric materials used in technological applications and theoretical research because of their exceptional properties based on micro-phase separation [22-26]. Block copolymers are largely used as resistant material. There are largely number of superior articles published on this subject [27-30].

We have reported RAFT-ROP and ATRP-ROP in our previous studies. They are combination of different techniques for synthesis of block and graft copoylmers. In this work, 3-bromo-1-propanol initiator was used, which allows different steps for both redox polymerization and ATRP polymerization. For this purpose, PMMA macroinitator (ATRP-macroinitiator) was synthesized by redox polymerization of methyl methacrylate (MMA) and 3-bromo-1-propanol. Ammonium cerium(IV) nitrate, [Ce( $\left.\left(\mathrm{NH}_{4}\right)_{2}\left(\mathrm{NO}_{3}\right)_{6}\right]$, was used as a catalyst for the redox polymerization. The synthesis of poly(methyl methacrylate)-b-poly $(N$ isopropylacrylamide) PMMA- $b$-PNIPAM block copolymers was carried out by means of ATRP of ATRP-macroinitiator and NIPAM at $60{ }^{\circ} \mathrm{C}$. Characterizations of the products are discussed in detail.

\section{EXPERIMENTAL SECTION}

\section{Materials}

3-Bromo-1-propanol, methyl methacrylate (MMA), $\mathrm{N}$-isopropylacrylamide (NIPAM) and copper(I) bromide $(\mathrm{CuBr})$ were obtained from Aldrich. $N, N, N^{\prime}, N^{\prime \prime}, N^{\prime \prime}-$ Pentamethyldiethylenetriamine (PMDETA) was supplied by Fluka. Methanol, N,N-Dimethylformamide (DMF) were obtained from Sigma-Aldrich and used as received. All other chemicals were reagent grade and used as received.

\section{Instrumentation}

The molecular weights and molecular-weight distributions were measured with Polymer Labs PL-GPC 220 and Malvern Viscotek RI-UV-GPC max gelpermeation chromatography (GPC) with THF as the solvent. A calibration curve was generated with three polystyrene standards: 2960, 50400, and $696500 \mathrm{Da}$, of low polydispersity. Fourier-transform infrared spectroscopy (FTIR) spectra were recorded with a PerkinElmer Spectrum 100 Model FTIR spectrometer in transmissive mode and scan rate from 4000 to 650 $\mathrm{cm}^{-1}$. ${ }^{1} \mathrm{H}$-nuclear magnetic resonance ( $\left.{ }^{1} \mathrm{H}-\mathrm{NMR}\right)$ spectra of the samples were recorded using a Bruker Ultra Shield Plus, ultra-long hold time $400 \mathrm{MHz}$ NMR spectrometer in $\mathrm{CDCl}_{3}$ as the solvent, with tetra methylsilane as the internal standard. Thermal analysis measurements of the polymers were carried out under nitrogen using a Perkin Elmer Pyris 1 TGA and Spectrum thermal analyzer to determine thermal degradation. Differential scanning calorimetry (DSC) measurements were carried out by using a Perkin Elmer Diamond DSC series thermal analysis system. Dried sample was heated at a rate of $10{ }^{\circ} \mathrm{C} / \mathrm{min}$ under nitrogen atmosphere.

\section{Procedure}

\section{Synthesis of ATRP-macroinitiator by redox polymerization}

For redox polymerization of MMA, $30 \mathrm{~mL}$ of MMA, $0.5 \mathrm{~g}$ of 3-bromo-1-propanol, and $2 \mathrm{~g}$ of $\mathrm{Ce}\left(\mathrm{NH}_{4}\right)_{2}\left(\mathrm{NO}_{3}\right)_{6}$ (as a catalyst) were placed into a 100 $\mathrm{mL}$ of flask equipped with a magnetic stirrer. Argon was subsequently purged into the tube through a needle. The flask was placed in water bath at $25^{\circ} \mathrm{C}$ for $24 \mathrm{~h}$. After the reaction, the reaction mixture was poured into an excess of methanol to precipitate ATRPmacroinitiator (PMMA-Br). ATRP-macroinitiator was dried under vacuum at room temperature for three days and was defined gravimetrically.

\section{Atom Transfer Radical Polymerization for PMMA-b- PNIPAM block copolymers}

PMMA-b-PNIPAM block copolymers were prepared by atomic transfer radical polymerization (ATRP) using the previously prepared PMMA-Br as the initiator. NIPAM, ATRP-macroinitiator, PMDETA and $\mathrm{CuBr}$ were charged separately into a Pyrex tube and were dissolved in DMF (The amounts of chemicals used in the polymerization are shown in Table 1 and 2). Next, argon was purged into the tube through a needle. The tube was tightly capped with a rubber septum and was placed in an oil bath at $60{ }^{\circ} \mathrm{C}$ for $16 \mathrm{~h}$. After the polymerization, the reaction mixture was poured into an excess of methanol to precipitate PMMA-b-PNIPAM block copolymer. The polymers were dried at $40{ }^{\circ} \mathrm{C}$ under vacuum for three days. The yield of the copolymer was determined gravimetrically. 


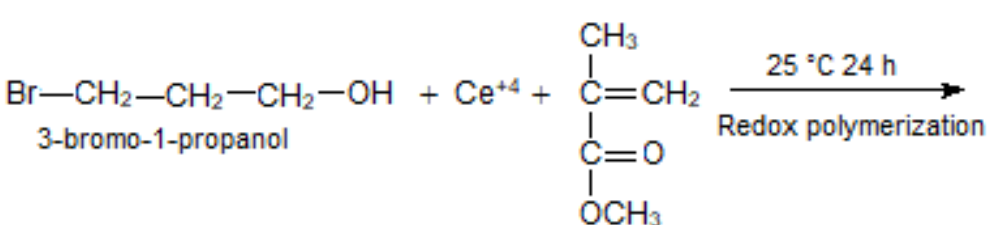

MMA<smiles>CCC1CCCCC1(C)C(C)(C)C(O)CCOC</smiles>

ATRP Macroinitiator<smiles>OCCCBr</smiles>

Scheme 1. Reaction pathways in the synthesis of ATRP macroinitiator

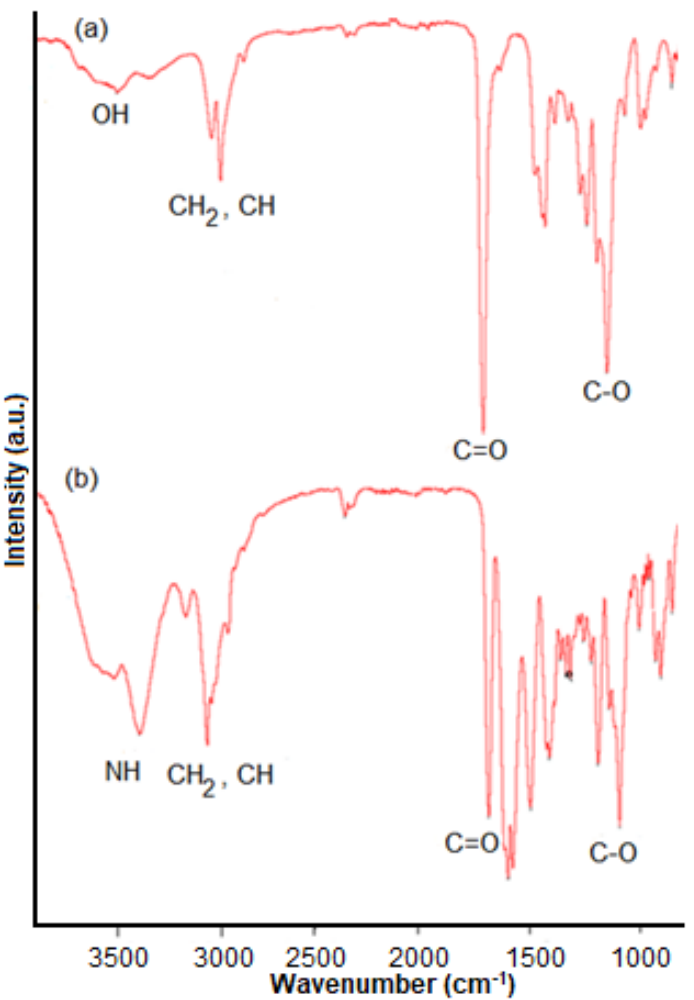

Fig 1. FTIR spectra of (a) ATRP-macroinitiator, and (b) PMMA-b-PNIPAM block copolymers

\section{RESULT AND DISCUSSION}

\section{Synthesis of ATRP-Macroinitiator}

ATRP-macroinitiator was synthesized by redox polymerization of MMA, and 3-bromo-1-propanol using $\mathrm{Ce}\left(\mathrm{NH}_{4}\right)_{2}\left(\mathrm{NO}_{3}\right)_{6}$ as a catalyst. The gravimetric conversion obtained from the weight of ATRPmacroinitiator was approximately $50 \mathrm{wt} \%$. The basic outline for the synthesis of ATRP macroinitiator is shown in Scheme 1.

The FTIR spectrum of ATRP-macroinitiator in Fig. 1(a) shows $3434 \mathrm{~cm}^{-1}$ for $-\mathrm{OH}$ groups, $2890 \mathrm{~cm}^{-1}$ for aliphatic $-\mathrm{CH}_{2}$ and $-\mathrm{CH}$ groups, $1728 \mathrm{~cm}^{-1}$ for $-\mathrm{C}=\mathrm{O}$ groups, and $1060 \mathrm{~cm}^{-1}$ for $-\mathrm{O}-\mathrm{C}$ groups.

The ${ }^{1} \mathrm{H}$-NMR spectrum of ATRP-macroinitiator in Fig. 2(a) shows the 3.6 ppm for $-\mathrm{OCH}_{3}$ protons of PMMA

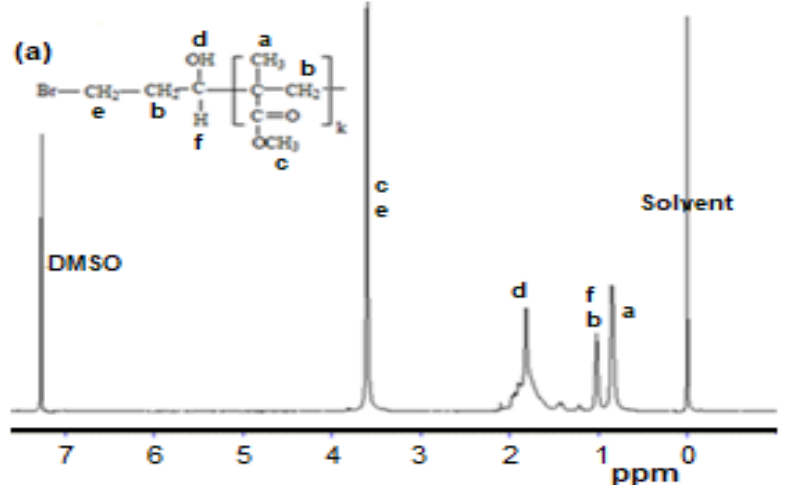

(b)
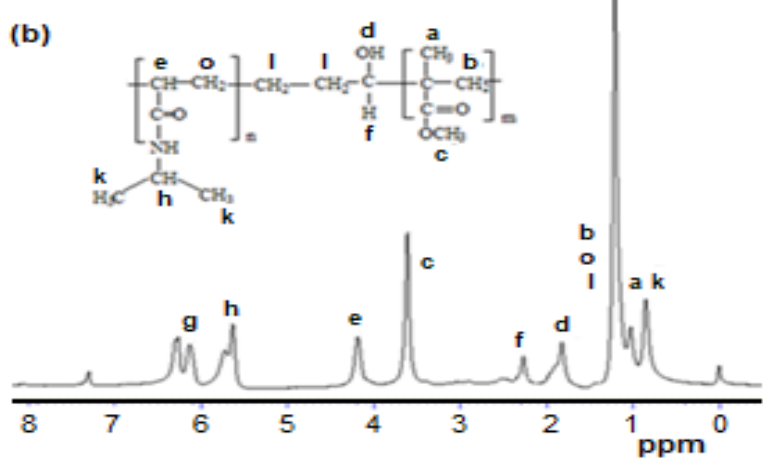

Fig 2. ${ }^{1} \mathrm{H}-\mathrm{NMR}$ spectra of (a) ATRP-macroinitiator, and (b) PMMA-b-PNIPAM block copolymers

segment and for $-\mathrm{BrCH}_{2}$ protons of 3-bromo-1propanol segment, $1.8 \mathrm{ppm}$ for $-\mathrm{OH}$ protons of 3 bromo-1-propanol segment, $1.0 \mathrm{ppm}-\mathrm{CH}_{2}$ protons of PMMA segment, - $\mathrm{CH}$ protons of 3-bromo-1-propanol segment, and $0.8 \mathrm{ppm}-\mathrm{CH}_{3}$ protons of PMMA segment.

\section{Atom Transfer Radical Polymerization for PMMA- $b$ - PNIPAM block copolymers}

Atom Transfer Radical Polymerization of NIPAM initiated by ATRP-macroinitiator provided PMMA- $b$ PNIPAM block copolymers. The basic outline for the synthesis of block copolymer is shown in Scheme 2. The effect of monomer and initiator concentration on the block copolymerization in the presence of ATRP macroinitiator by the application of ATRP process have 
been studied. The results of the copolymerization of NIPAM are shown in Table 1 and Table 2. The monomer conversion was calculated from the weight of recovered polymer. The conversion of the monomer was between 19.08 and 84.98 wt.\%. Increase in the molecular weights of the copolymers as compared with molecular weight of the initiator can confirm block copolymer formation.

FTIR spectrum of PMMA- $b$-PNIPAM block copolymer in Fig. 1(b) shows the signals at $3800 \mathrm{~cm}^{-1}$ for $-\mathrm{NH}$ groups, $2890 \mathrm{~cm}^{-1}$ for aliphatic $-\mathrm{CH}_{2},-\mathrm{CH}$ groups, $1728 \mathrm{~cm}^{-1}$ for $-\mathrm{C}=\mathrm{O}$ groups, $1060 \mathrm{~cm}^{-1}$ for $-\mathrm{O}-\mathrm{C}$ groups.

The ${ }^{1} \mathrm{H}$-NMR spectrum of the block copolymers in Fig. 2(b) shows $0.8 \mathrm{ppm}$ for aliphatic $-\mathrm{CH}_{3}$ protons of PNIPAM and PMMA segment, 1.2 ppm for aliphatic $\mathrm{CH}_{2}$ protons of PMMA segment, $-\mathrm{CH}_{2}$ protons of 3bromo-1-propanol segment and $-\mathrm{CH}_{2}$ protons of PNIPAM segment, $1.8 \mathrm{ppm}$ for $-\mathrm{OH}$ protons of 3-bromo1-propanol segment, $2.2 \mathrm{ppm}-\mathrm{CH}$ protons of 3-bromo1-propanol segment, $3.6 \mathrm{ppm}$ for $-\mathrm{OCH}_{3}$ protons PMMA segment, $4.3 \mathrm{ppm}$ for $-\mathrm{CH}$ of PNIPAM segment, 5.7 ppm - $\mathrm{CH}$ of PNIPAM segment, and $6.3 \mathrm{ppm}$ for $-\mathrm{NH}$ protons PNIPAM segment.

Dependence of NIPAM concentration on number average molecular weight $(\mathrm{Mn})$ for the copolymerization is shown in Table 1. Relatively, increasing the amount of monomers also causes an increase in both the yield and the molecular weights of the copolymers as expected (Table 1).

Dependence of ATRP macroinitiator concentration on number average molecular weight $(\mathrm{Mn})$ for the block copolymerization is shown in Table 2. Increasing the amount of ATRP macroinitiator causes an increase in the molecular weights of the copolymer. Interestingly, the value of $\mathrm{Mn}$ can only decrease if new chains are generated. However, that is not in accordance with a controlled polymerization. Increased amounts of initiator in the reaction mixture lead to the formation of a higher number of active centers. Consequently, increased numbers of growing radicals are formed in the system. Hence, it may be expected that they have shorter PNIPAM segments, which is confirmed by a decrease in the molecular weights of the block copolymers, as shown in Table 2. The same situation was also observed in our previous articles [9,11]. Furthermore, dependence of ATRP macroinitiator concentration on conversion (wt.\%) for the block copolymerization is also shown in Table 2. Higher amounts of ATRP macro initiator cause higher polymer yield as expected.

The $\mathrm{Mw} / \mathrm{Mn}$ values of the block copolymers are between 2.03 and 2.17 (Table 1 and 2). Because of the use of a macroinitiator having very broad molecular weight distribution, $\mathrm{Mw} / \mathrm{Mn}$ values of the block copolymers are relatively higher than expected. All the block copolymers have GPC chromatograms. Fig. 3<smiles>CCC1CCCC(C)(C(=O)OC)C(O)C1</smiles>

ATRP Macroinitiator

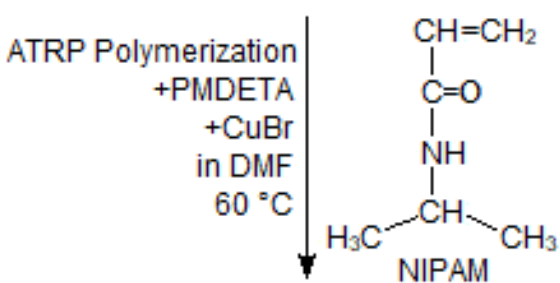<smiles>CCC(CC1C(=O)NC(C)CC1(CC)CC)CC(CC)(C(C)C)C(O)CCC(CC)C(=O)OC</smiles>

Poly(MMA-b-NIPAM) block copolymers

Scheme 2. Reaction pathways in the synthesis of PMMA-b-PNIPAM block copolymers

Table 1. The effect of the amount of the monomer on copolymerization for PMMA- $b$-PNIPAM block copolymers

\begin{tabular}{ccccccccc}
\hline Code & Poly(MMA) (g) & NIPAM (g) & CuBr (g) & PMDETA (g) & Yield $(\mathrm{g})$ & Conv. (wt.\%) & $\mathrm{M}_{\mathrm{n}, \mathrm{GPC}}$ & $\mathrm{M}_{\mathrm{w}} / \mathrm{M}_{\mathrm{n}}$ \\
\hline MG-1 & 0.012 & 0.50 & 0.016 & 0.08 & 0.334 & 65.23 & 57,500 & 2.14 \\
MG-2 & 0.012 & 0.75 & 0.016 & 0.08 & 0.540 & 70.86 & 59,800 & 2.13 \\
MG-3 & 0.012 & 1.00 & 0.016 & 0.08 & 0.860 & 84.98 & 57,700 & 2.17 \\
\hline
\end{tabular}

Table 2. The effect of the amount of ATRP macroinitiator on polymerization for PMMA- $b$-PNIPAM block copolymers

\begin{tabular}{lcccccccc}
\hline Code & Poly(MMA) $(\mathrm{g})$ & NIPAM $(\mathrm{g})$ & CuBr $(\mathrm{g})$ & PMDETA $(\mathrm{g})$ & Yield $(\mathrm{g})$ & Conv. (wt.\%) & $\mathrm{M}_{\mathrm{nGPC}}$ & $\mathrm{M}_{\mathrm{w}} / \mathrm{M}_{\mathrm{n}}$ \\
\hline $\mathrm{M}-1$ & 0.024 & 0.50 & 0.016 & 0.08 & 0.100 & 19.08 & 65,700 & 2.04 \\
$\mathrm{M}-2$ & 0.048 & 0.50 & 0.032 & 0.16 & 0.180 & 32.85 & 67,500 & 2.03 \\
$\mathrm{M}-3$ & 0.096 & 0.50 & 0.064 & 0.32 & 0.200 & 34.00 & 58,300 & 2.16 \\
\hline
\end{tabular}




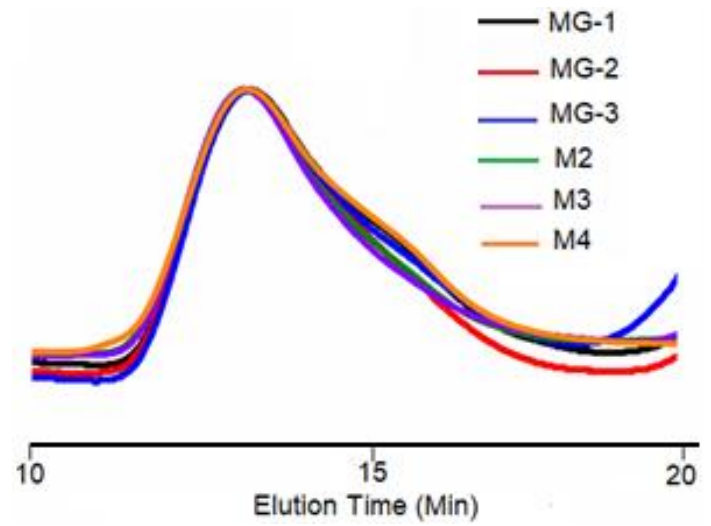

Fig 3. GPC curve of PMMA-b-PNIPAM block copolymers

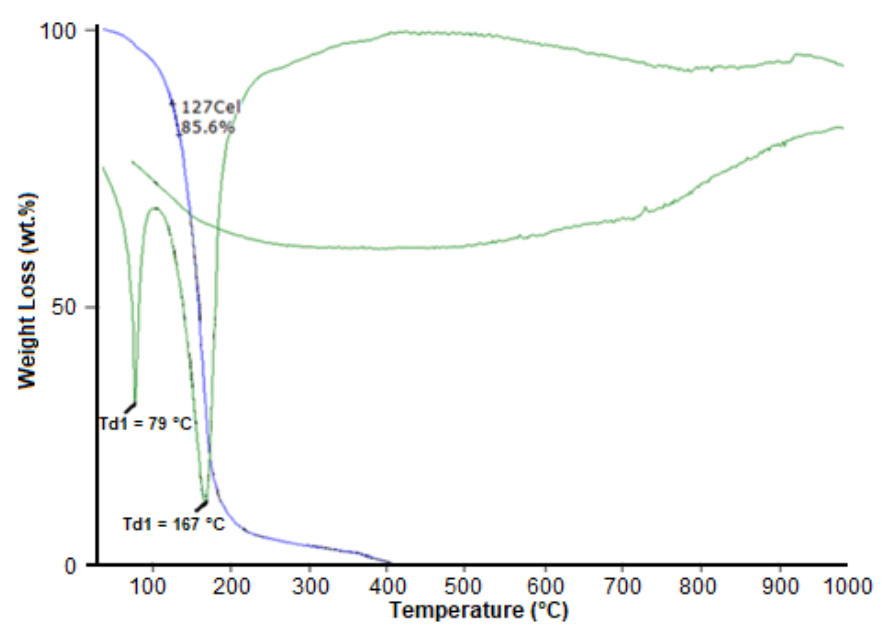

Fig 4. TGA curves of PMMA-b-PNIPAM block copolymers (MG-2 in Table 1)

shows the unimodal GPC curves of the graft copolymers (MG-1, MG-2, and MG-3 in Table 1, and M-2, M-3 and M-4 in Table 2).

Thermal analysis of the samples was carried out by taking TGA curves. TGA showed interesting properties of the block copolymer indicating continuous weight loss starting from $10{ }^{\circ} \mathrm{C}$ to $500{ }^{\circ} \mathrm{C}$. In the case of PMMA-bPNIPAM block copolymer (MG-2), PNIPAM, PMMA blocks had the individual decomposition temperatures as shown in Fig. 4 [ca. 79 and $167^{\circ} \mathrm{C}$, respectively].

\section{CONCLUSION}

A macromonomer initiator (ATRP macroinitiator) was synthesized by redox polymerization. ATRP macroinitiator was used as initiator for ATRP polymerization which is one of the controlled radical polymerization methods. Block copolymers synthesized by methods such as ATRP, RAFT and NMP have applied in various medical and biomedical processes. Macro ATRP initiator including poly-MMA has demonstrated the characteristic macroinitiator behavior in the copolymerization of NIPAM. A set of synthesis, ATRP polymerization conditions of the block copolymers poly(MMA- $b$-NIPAM), were obtained. The block copolymers were relatively obtained in high yield and molar weight. In this study, poly(MMA-b-NIPAM) block copolymers have added via ATRP and Redox polymerization techniques. The proposed procedure for the preparation of block copolymers is simple and efficient than conventional free radical polymerization. The synthesized macroinitiator, as an initiator for different polymerization techniques such as RAFT polymerization and "CLICK" Chemıstry, can be used to synthesize block copolymers.

\section{ACKNOWLEDGEMENT}

This work was supported by the Yüzünci Yıl University Scientific Research Fund (grand number: FBA-2016-5036).

\section{REFERENCES}

[1] Zaremski, M., Eremeev, I., Garina, E., Borisova, O., and Korolev, B., 2017, Controlled synthesis of random, block-random and gradient styrene, methyl methacrylate and acrylonitrile Terpolymers via nitroxide-mediated free radical polymerization, J. Polym. Res., 24 (9), 151.

[2] Okada, S., and Matyjaszewski, K., 2015, Synthesis of bio-based poly( $N$-phenylitaconimide) by atom transfer radical polymerization, J. Polym. Sci., Part A: Polym. Chem., 53 (6), 822-827.

[3] Han, D.H., and Pan, C.Y., 2007, Preparation and characterization of heteroarm $\mathrm{H}$-shaped terpolymers by combination of reversible additionfragmentation transfer polymerization and ringopening polymerization, J. Polym. Sci., Part A: Polym. Chem., 45 (5), 789-799.

[4] Shipp, D.A., Wang, J., and Matyjaszewski, K., 1998, Synthesis of acrylate and methacrylate block copolymers using atom transfer radical polymerization, Macromolecules, 31 (23), 80058008.

[5] Wi, Y., Lee, K., Hyung, B., and Choe, S., 2008, Soap-free emulsion polymerization of styrene using poly(methacrylic acid) macro-RAFT agent, Polymer, 49 (26), 5626-5635.

[6] Göktaş, M., Öztürk, T., Atalar, M.N., Tekeş, A.T., and Hazer, B., 2014, One-step synthesis of triblock copolymers via simultaneous reversibleaddition fragmentation chain transfer (RAFT) and ring-opening polymerization using a novel difunctional macro-RAFT agent based on 
polyethylene glycol, J. Macromol. Sci. Part A Pure Appl. Chem., 51 (11), 854-863.

[7] Hong, J., Wang, Q., and Fan, Z., 2006, Synthesis of multiblock polymer containing narrow polydispersity blocks, Macromol. Rapid. Commun., 27, 57-62.

[8] Rwei, S.P., Chuang, Y.Y., and Way, T.F., 2015, Preparation of thermo-responsive star copolymers via ATRP and its use in drug release application, Colloid Polym. Sci., 293 (2), 493-503.

[9] Öztürk, T., Göktaş, M., and Hazer, B., 2010, Onestep synthesis of triarm block copolymers via simultaneous reversible-addition fragmentation chain transfer and ring-opening polymerization, $J$. Appl. Polym. Sci., 117 (3), 1638-1645.

[10] Wang, J.S., and Matyjaszewski, K., 1995, Controlled/"Living" radical polymerization. Halogen atom transfer radical polymerization promoted by a $\mathrm{Cu}(\mathrm{I}) / \mathrm{Cu}(\mathrm{II})$ redox process, Macromolecules, 28 (23), 7901-7910.

[11] Öztürk, T., Yavuz, M., Göktaş, M., and Hazer, B., 2016, One-step synthesis of triarm block copolymers by simultaneous atom transfer radical and ring-opening polymerization, Polym. Bull., 73 (6), 1497-1513.

[12] Ozturk, T., Yilmaz, S.S., and Hazer, B., 2008, Synthesis of a new macroperoxy initiator with methyl methacrylate and t-butyl peroxy ester by atom transfer radical polymerization and copolymerization with conventional vinyl monomers, J. Macromol. Sci. Part A Pure Appl. Chem., 45 (10), 811-820.

[13] Yu, W.N., Liu, S.X., Wang, H.M., and Tian, R., 2012, Synthesis an micellization of P(NIPAM-coHMAM)-b-P(NIPAM-co-HMAM) triblock copolymers, J. Polym. Res., 19 (11), 9989.

[14] Öztürk, T., Kayğın, O., Göktaş, M., and Hazer, B., 2016, Synthesis and characterization of graft copolymers based on polyepichlorohydrin via reversible addition-fragmentation chain transfer polymerization, J. Macromol. Sci. Part A Pure Appl. Chem., 53 (6), 362-367.

[15] Hazer, B., Çakmak, İ., Denizligil, S., and Yağcı, Y., 1992, Preparation of multiphase block copolymers by redox polymerization, Angew. Makromol. Chem., 195 (1), 121-127.

[16] Erciyes, A.T., Erim, M., Hazer, B., and Yağcl, Y., 1992, Synthesis of polyacrylamide flocculants with PEG segments by redox polymerization, Angew. Makromol. Chem., 200, 163-171.

[17] Arslan, H., Eroglu, M.S., and Hazer, B., 2001, Ceric ion initiation of methyl methacrylate from poly(glycidyl azide)-diol, Eur. Polym. J., 37 (3), 581585.

[18] Stoeckel, N., Wieland, P.C., and Nuyken, O., 2002, New synthesis of graft copolymers using the DPE- technique: ATRP graft copolymerization, Polym. Bull., 49 (4), 243-250.

[19] Öztürk, T., Atalar., M.N., Göktaş, M., and Hazer, B., 2013, One-step synthesis of block graft copolymers via simultaneous reversible-addition fragmentation chain transfer and ring-opening polymerization using a novel macroinitiator, $J$. Polym. Sci., Part A: Polym. Chem., 51 (12), 26512659.

[20] Öztürk, T., and Hazer, B., 2010, Synthesis and characterization of a novel macromonomer initiator for reversible addition fragmentation chain transfer (RAFT). Evaluation of the polymerization kinetics and gelation behaviors, J. Macromol. Sci. Part A Pure Appl. Chem., 47 (3), 265-272.

[21] Öztürk, T., Göktaş, M., Savaş, B., Işıklar, M., Atalar, M.N., and Hazer, B., 2014, Synthesis and characterization of poly(vinylchloride-graft-2vinylpyridine) graft copolymersusing a novel macroinitiator by reversible addition-fragmentation chain transfer polymerization, e-Polymers, 14 (1), 27-34.

[22] Hazer, B., 1991, Synthesis of styrenetetrahydrofuran branched block copolymers, Eur. Polym. J., 27 (9), 975-978.

[23] Öztürk, T., Göktaş, M., and Hazer, B., 2011, Synthesis and characterization of poly(methyl methacrylate-block-ethylene glycol-block-methyl methacrylate) block copolymers by reversible addition-fragmentation chain transfer polymerization, J. Macromol. Sci. Part A Pure Appl. Chem., 48 (1), 65-72.

[24] Bosman, A.W., Vestberg, R., Heumann, A., Frechet, J.M.J., and Hawker, C.J.J., 2003, A modular approach toward functionalized threedimensional macromolecules: From synthetic concepts to practical applications, J. Am. Chem. Soc., 125 (3), 715-728.

[25] Haraguchi, N., and Hirao, A., 2003, Synthesis of well-defined star-linear block polystyrenes by coupling reaction of chain-functionalized polystyrenes with a definite number of benzyl bromide moieties with polystyryllithiums, Macromolecules, 36 (25), 9364-9372.

[26] Li, Z., Hillmyer, M.A., and Lodge, T.P., 2004, Synthesis and characterization of triptych $\mu-A B C$ star triblock copolymers, Macromolecules, 37 (24), 8933-8940.

[27] Shinoda, H., and Matyjaszewski, K., 2001, Improving the structural control of graft copolymers. Copolymerization of poly (dimethyl siloxane) macromonomer with methyl methacrylate using RAFT polymerization, Macromol. Rapid Commun., 22 (14), 1176-1181. 
[28] Chen, M., Ghiggino, K.P., Launikonis, A., Mau, AWH., Rizzardo, E., Sasse, WHF., Thang, SH., and Wilson, G.J., 2003, RAFT synthesis of linear and star-shaped light harvesting polymers using di- and hexafunctional ruthenium polypyridine reagents, $J$. Mater. Chem., 13 (11) 2696-2700.

[29] Roy, D., Guthrie, J.T., and Perrier, S., 2005, Graft polymerization: grafting poly(styrene) from cellulose via reversible addition-fragmentation chain transfer
(RAFT) polymerization, Macromolecules, 38 (25), 10363-13372.

[30] Fragouli, P.G., latrou, H., Hadjichristidis, N., Sakurai, T., and Hirao, A., 2006, Synthesis and characterization of model 3-miktoarm star copolymers of poly(dimethylsiloxane) and poly(2vinylpyridine), J. Polym. Sci., Part A: Polym. Chem., 44 (1), 614-619. 